\title{
PELANGGARAN PRINSIP KERJA SAMA DALAM PERCAKAPAN NAJWA SHIHAB DAN JOKO WIDODO DI METRO TV
}

\author{
Ella Citra ${ }^{1)}$ \\ ${ }^{1}$ Pendidikan Bahasa dan Sastra Indonesia, Fakultas Ilmu Tarbiyah dan Pendidikan, Universitas Islam Negeri Syarif \\ Hidayatullah Jakarta, J1. Ir. H. Djuanda No.95, Ciputat, Tangerang Selatan, Banten 15412, Indonesia. \\ E-mail:_ella.citra1998@gmail.com
}

\begin{abstract}
Abstrak
Percakapan tokoh-tokoh besar di Indonesia yang sering di tanyangkan di televisi menjadi salah satu sarana bagi masyarakat luas dalam memperoleh informasi. banyaknya acara-acara televisi yang menampilkan tokoh-tokoh besar, satu diantaranya acara Mata Najwa. Tulisan ini bertujuan untuk mendeskripsikan pelanggaran percakapan yang terjadi dalam acara Mata Najwa. Pelanggaran percakapan yang terjadi antara Najwa Shihab dengan Joko Widodo, merupakan bentuk pelanggaran prinsip kerja sama dalam kajian pragmatik. Metode penelitian yang digunakan dalam tulisan ini adalah metode deskriptif kualitatif. Adapun sumber data dalam penelitian ini berasal dari rekaman video dan audio tuturan Najwa Shihab dengan Joko Widodo dalam acara Mata Najwa Metro TV. Data dalam penelitian ini berupa percakapan antara Najwa Shihab dengan Joko Widodo pada episode "Menyambut Presiden Pilihan Rakyat" yang dipublikasikan tanggal 6 Agustus 2014. Analisis data dilakukan dengan langkah mentranskripsi data, kemudian menganalisis data tersebut dengan cara mengelompokkan percakapan-percakapan yang mengalami pelanggaran prinsip kerja sama, yaitu pelanggaran maksim kuantitas, maksim kualitas, maksim relevansi, dan maksim cara. Hasil analisis membuktikan terdapat beberapa percakapan yang melanggar prinsip kerja sama, hal tersebut mungkin saja disebabkan oleh faktor kepentingan, faktor tujuan dan faktor situasi.
\end{abstract}

Kata Kunci: Prinsip Kerja Sama; Joko Widodo; Pragmatik.

\begin{abstract}
The conversations of big figures in Indonesia that are often broadcast on television are a means for the wider community to obtain information. many television programs featuring big figures, one of which is the Mata Najwa program. This paper aims to describe the conversations that took place at the Mata Najwa event. The conversation violation that occurred between Najwa Shihab and Joko Widodo was a form of cooperation principle in pragmatic studies. The research method used in this paper is a qualitative descriptive method. The data sources in this study came from the video and audio recordings of Najwa Shihab's speech with Joko Widodo in the Mata Najwa Metro Tv event. The data in this research is in the form of the initiative between Najwa Shihab and Joko Widodo in the episode "Welcoming the President's Choice of the People" which was published on August 6, 2014. Data analysis was carried out by transcribing the data, then analyzing the data by grouping groups that experienced cooperative methods, namely maxim of quantity, maxim of quality, maxim of relevance, and maxim of method. The results of the analysis prove that several cases have violated the principle of cooperation, this may be caused by factors of interest, objective factors and situation factors. Through this research, it is hoped that it can become a reference for further research.
\end{abstract}

Keywords: The Principle of Cooperation; Joko Widodo; Pragmatics.

\section{PENDAHULUAN}

Bahasa adalah alat komunikasi manusia dalam bertutur antara sesama manusia dan ini hampir setiap hari dilakukan. Bahasa dan komunikasi merupakan dua hal yang saling berkaitan. Proses berbahasa antar individu tidak dapat disamakan satu dengan yang lainnya, karena proses berbahasa adalah suatu proses yang bersifat individu. Proses berbahasa seseorang berbeda satu dengan yang lainnya dapat dipengaruhi oleh lingkungan, pengalaman, tujuan, dan budaya setempat. Berbahasa merupakan bentuk konkret dari fikiran manusia dalam menyampaikan apapun yang ia rasakan. Sejalan dengan yang disampaikan (Komalasari, 2019) menjelaskan bahwa secara garis besar fungsi utama Bahasa yaitu sebagai alat komunikasi untuk menyatakan ekspresi diri, mengadakan integrasi dan adaptasi sosial sekaligus untuk 
menyatakan kontrol sosial. Dengan demikian sudah jelas bahwa fungsi utama bahasa sebagai alat komunikasi dalam menyampaikan pesan atau makna oleh seseorang kepada orang lain.

Berbahasa mencakup dua aspek yang tertuang dalam jurnal (Setiawan et al., 2017) yaitu aspek linguistik dan aspek non-liguistik atau pralinguistik. Aspek linguistik mencakup tataran fonologi, morfologi, dan sintaksis. (Chaer, 2014) menyatakan aspek pralinguistik mencakup kualitas ujaran, unsur suprasegmental (tekanan, nada, dan intonasi), jarak dan gerak gerik tubuh. Linguistik merupakan ilmu yang memperlakukan bahasa sebagai bahasa. kemudian (Nuryani, 2013) menyatakan bahwa Linguistik tidak hanya membahas tentang satu bahasa saja melainkan juga seluk beluk bahasa. Seperti yang dikatakan tadi lingustik mencakup 3 tataran yaitu, fonologi, merupakan subdisiplin linguistik yang mengkaji bunyi bahasa secara umum. Morfologi, berkaitan dengan proses pembentukan kata dan jenis-jenis bentuk kata. Sedangakn sintaksis megacu kepada kemampuan menyusun satuan-satuan lingual yang berupa kata menjadi satuan linguallingual yang lebih besar berupa frasa, klausa, dan kalimat untuk tujuan komunikasi (Nuryani, 2013).

Bahasa sebagai alat komunikasi yang terjadi dan dilakukan oleh penutur dapatlah dikaji dari segi internal maupun eksternal, secara eksternal bahasa dilihat dari luar bahasanya. Seperti bahasa yang terjadi antara penutur dan lawan tutur dalam berkomunikasi di masyarakat (Fauziah et al., 2018). Termasuk ketika dalam acara tanya jawab yang melibatkan penutur dan lawan tutur. Tuturan yang disampaikan oleh penutur kepada lawan tutur tentu akan berpengaruh terhadap konteks yang dimaksud penutur. Pada suatu situasi percakapan yang melibatkan penutur dengan lawan tutur tentu diantara mereka harus ada kerja sama satu dengan yang lainnya agar maksud komunikasi yang disampaikan dapat diterima dengan baik.

Kerja sama antar warga masyarakat atau kemunitas bahasa diantaranya dapat dilakukan dengan cara mematuhi sejumlah prinsip dan maksim; diantaranya adalah seperangkat kaidah dan norma, yakni kaidah dan norma sosial yang berlaku pada masyarakat itu. Berkatan dengan kerja sama dalam konteks komuikasi antara penutur dan mitra tutur. Di dalam prinsip kerja sama Grice sesungguhnya hendak ditegaskan bahwa dalam aktivitas berbahasa harus ada semacam kerja sama antara pihak penutur dan mitra tutur atau antara penyapa dan pesapa, atau antara pihak utterrer dan interpeter (Rahardi, Kunjana, Yuliana Setyaningsih, 2016). Kerja sama antara penutut dan kawan tutur perlu dilakukan agar situasi percakapan yang sedang berlangsung tetap dalam situasi baik dan efisien. Di dalam kegiatan pecakapan tentu sangat memungkinkan terjadinyan pelanggaran prinsip kerja sama. pelangagran prinsip kerja sama dapat terjadia secara sengaja maupun tidak sengaja. Pelanggarang prinsip kerja sama sering terjadi dikarenakan kurangnya pemahaman penutur maupun lawan tutur tentang adanya prinsip kerja sama yang harus dipatuhi dalam bertutur. Tetapi dalam beberapa kasus sering kali pelanggaran prinsip kerja sama yang terjadi karena adanya faktor kesengajaan dari salah satu pihak untuk memenuhi maksud dan tujuan tertentu yang hendak ia capai.

Tercapainya kontribusi atau kerja sama dalam percakapan tentu penutur maupun lawan tutur harus memahami terlebih dahulu dengan baik mengenai prinsip kerja sama. prinsip kerja sama yang kemudian dibagi menjadi empat kategori maksim, yaitu maksim kuantitas, maksim kualitas, maksim relevansi, dan maksim cara. Secara umum kita dapat mendefinisikan pragmatik merupakan salah satu cabang ilmu bahasa yang boleh dikatakan berbeda dengan ilmu bahasa strukturalis. Pragmatik merupakan ilmu bahasa yang mempelajari relasi antara tanda, makna dan konteks (Surastina, 2011) berpendapat bahwa pragmatik merupakan studi terhadap semua hubungan antara bahasa dan konteks yang digramatikalisasikan atau ditandai di dalam struktur bahasa. Selanjutnya Wijana berpendapat bahwa pragmatik adalah cabang 
ilmu bahasa yang mempelajari struktur bahasa secara eksternal, yakni bagaimana kesatuan kebahasaan digunakan dalam komunikasi. Menurut Yule yang merupakan salah satu tokoh dalam ilmu pragmatik berpendapat bahwa pragmatik merupakan ilmu yang meneliti makna yang dikomunikasikan oleh pembicara dan diterjemahkan oleh pendengar atau pembaca. Terdapat beberapa hal yang harus dipertimbangkan dalam kajian ini, seperti siapa lawan bicaranya, di mana, kapan, dan dalam situasi apa (Yusri, 2016).

Menurut Darjowidjojo (Surastina, 2011: 3) salah satu bentuk umum dipelajari dalam analisis kemampuan pragmatik adalah dengan menganalisa percakapan yang dibuat seseorang dengan orang dewasa atau anak lain. Oleh karena itu, penting bagi kita untuk memahami aspek situasi tutur. Aspek-aspek tersebut adalah sebagi berikut: (1) Penutur dan lawan tutur, konsep penutur dan lawan tutur ini juga mencakup penulis dan pembaca bila tuturan bersangkutan dikomunikasikan dengan media tulisan. Aspek-aspek yang berkaitan dengan penutur dan lawan tutur ini adalah usia, latar belakang sosial ekonomi, jenis kelamin, tingkat keakraban. (2) Konteks tuturan, konteks tututan penelitian linguistik adalah konteks dalam semua aspek fisik atau seting sosial yang relevan dari tuturan bersangkutan. Di dalam pragmatik konteks itu pada hakikatnya adalah semua latar belakang pengatahuan yang dipahami bersama oleh penutur dan lawan tutur. Leech mengartikan konteks sebagai suatu pengetahuan latar belakang yang sama-sama dimiliki oleh penutur dan lawan tutur. (3) Tujuan tuturan, bentuk-bentuk tuturan yang diutarakan oleh penutur dilatarbelakangi oleh maksud dan tujuan. Dalam hubungan itu bentuk-bentuk tuturan yang bernacam-macam dapat digunakan untuk menyatakan maksud dan tujuan. Di dalam pragmatik berbicara merupakan aktivitas yang berorirntasi pada tujuan. (4) Tuturan sebagai bentuk tindakan atau aktivitas, pragmatik berhubungan dengan tindak verbal yang terjadi dalam situasi tertentu. Tuturan sebagai entitas yang konkret jelas penutur dan lawan tuturnya, serta waktu dan tempat pengutraannya. (5) Tuturan sebagai produk tindak verbal, tuturan yang digunakan di dalam rangkaian pragmatik, seperti yang dikemukakan dalam keempat kriteria merupakan bentuk dari tindak tutur. Oleh karena itu, tuturan yang dihasilkan merupakan bentuk dari tindak verbal (Samad, 2017).

Terdapat empat jenis maksim dalam prinsip kerja sama yaitu (1) Maksim kuantitas merupakan sebuah pemberian informasi yang menekankan penutur untuk memberi informasi yang cukup, dan seinformatif mungkin, tidak kurang tetapi juga tidak berlebihan. Prinsip dari maksim kuantitas adalah menghendaki setiap kawan tutur maupun penutur, untuk memberikan informasi sesuai tidak kurang dan tidak lebih (Achsani, 2019). (2) Maksim kualitas, ditegaskan bahwa penutur maupun mitra tutur, di dalam sebuah pertututuran haruslah mengatakan sesuatu yang sebenarnya, sesuatu yang sesuai dengan kenyataannya. Apabila seseorang tidak berbicara sesuai dengan yang seharusnya, alias tidak menyampaikan yang sesungguhnya, harus dikatakan bahwa tuturan itu tidak sejalan dengan maksim kualitas sebagaimana yang disampaikan H. P. Grice (Rahardi, Kunjana, Yuliana Setyaningsih, 2016). (3) Maksim relevansi merupakan sebuah batasan dalam pemberian informasi, pada batasan ini seorang penutur maupun mitra tutur dituntut untuk bekerja sama dalam menyampaikan informasi agar terbentuk nya percakapan yang relevansi terhadap topik yang dibicarakan (Rahardi, Kunjana, Yuliana Setyaningsih, 2016). (4) Maksim cara ditegaskan bahwa, agar komunikasi dapat berjalan dengan baik dan lancar, setiap peserta percakapan haruslah selalu berbicara secara jelas dan tidak kabur.

Dengan berbicara yang jelas, tidak dimungkinkan terjadinya salah pengertian dan salah paham. Maka, dimensi sangat penting pertama disampaikan Grice dalam maksim cara, orang menyampaikan sesuatu, alias berekspresi, haruslah disampaikan dengan secara terang dan sejelas-jelasnya. Hal kedua yang juga ditegaskan oleh Grice dalah masalah 'ambiguility' alias ketaksaan atau 'ambiguitas'. 
Artinya, pertuturan itu tidak boleh bermakna ganda atau dimungkinkan untuk ditafsirkan oleh seseorang secara 'ganda'. Hal ketiga adalah "be brief". Selalu berusaha berbicara ringkas, tidak berpanjang-panjang dan tidak berbelit-belit. Orang yang berbicara dengan tidak 'ringkas', 'pendek' dan 'padat' alias 'brief' dipastikan melanggar, atau setidaknya tidak mendukung maksim cara dalam prinsip kerja sama Grice (Rahardi, Kunjana, Yuliana Setyaningsih, 2016).

Penelitian ini berfokus pada pelanggaran prinsip kerja sama yang terjadi dalam acara Mata Najwa di Metro TV episode Menyambut Presiden Pilihan Rakyat. Percakapan pada acara tersebut terjadi antara Najwa Shihab sebagai tuan rumah dan Joko Widodo sebagai bintang tamu atau narasumber. Pelangaranpelanggaran yang terjadi dalam acara tersebut berupa pelanggaran maksim kuantitas, pelanggaran maksim kualitas, pelanggaran maksim relevan dan pelanggaran maksim cara. Pelanggaran prinsip kerja sama yang terjadi dalam acara ini terjadi antara seorang pembawa acara dengan bintang tamunya seorang presiden Indonesia. Dengan demikian, perlu dilakukan penelitian mengenai pelanggaran prinsip kerja sama dalam percakapan dua orang penting ini, untuk melihat masihkah sering terjadi pelanggaran prinsip kerja sama dalam percakapan resmi yang disiarkan langsung di televisi.

\section{KAJIAN LITERATUR}

Terdapat tiga kajian lieratur yang mendukung penelitian ini. Sebelumnya peneliti tidak menemukan lieteratur yang bahasannya sama persisi dengan judul peneliti.

Penelitian pertama berjudul "Pelenggaran Prinsip Kerja Sama pada Sinetron Preman Pensiun" penelitian ini dilakukan oleh Veria Septianingtias. Penelitian Veria dengan penelitian ini sama-sama membahas tentang pelanggaran prinsip kerja sama, namun bedanya penelitian ini mengambil subjek percakapan antara Joko Widodo dan Najwa Shihab, sedangkan penelitian Veria sujeknya adalah sinetron preman pensiun. penelitian kedua berjudul "Penerapan Prinsip Kerja Sama dan Prinsip Kesopanan dalam Tuturan IR. Joko Widodo pada Video Debat Pilpres 2019" penelitian ini dilakukan oleh Ni Luh Putu Yumi Kusuma, dkk. Penelitian Ni Luh dengan penelitian ini sama-sama menggunkan tuturan Joko Widodo sebagai subjek dalam penelitian, namun penelitian Ni Luh membahas tentang penerapan prinsip kerja sama dan kesopanan, sedangkan penelitian ini membahas tentang pelanggaran prinsip kerja sama dalam tuturan. penelitian ketiga berjudul "Pelanggaran Maksim Kesopanan dalam Kolom Komentar Twitter Joko Widodo" penelitian ini ditulis oleh Kunti Zahrotun. penelitian Kunti dengan penelitian ini sama-sama menjadikan Jowo Widodo menjadi subjek dalam penelitian, namun penelitian Kunti hanya mengfokuskan pada maksim Kesopanan, sedangkan penelitian ini berfokus pada pelanggaran prinsip kerja sama.

\section{METODE PENELITIAN}

Metode yang digunakan dalam penelitian ini yaitu metode deskriptif, metode ini bertujuan untuk mendeskripsikan pelanggaran yang terjadi dalam percakapan antara Najwa Shihab dengan Joko Widodo dalam acara Mata najwa di Metro TV episode "Menyambut Presiden Pilihan Rakyat". Pelanggaran yang terjadi dalam acara Mata Najwa akan dianalisis dan dideskripsikan dalam penelitian ini. Adapun bentuk penelitian ini ialah kualitatif. (Sudaryanto, 1993) menyebutkan bahwa penelitian deskriptif adalah penelitian yang dilakukan berdasarkan fakta dan fenomena yang memang secara empiris hidup pada penutur-penuturnya, sehingga yang dihasilkan atau dicatat berupa perian bahasa yang bisa dikatakan sifatnya seperti potret. (Mahsun, 2007) berpendapat bahwa penelitian kualitatif adalah penelitian yang berfokus menunjukkan makna, deskripsi, penjernihan, dan penempatan data pada konteksnya masing-masing dan sering kali melukiskannya dalam bentuk katakata daripada angka-angka. 
Sumber data yang digunakan dalam penelitian ini ialah rekaman dan trankripsi video percakapan antara Najwa Shihab dengan Joko Widodo dalam acara Mata Najwa di Metro TV, yang saya peroleh lewat Youtube. Adapun teknik dalam penelitan ini melalui langkahlangkah menonton video, kemudian melakukan transkripsi data, dan yang terakhir membaca transkripsi untuk kemudian menganalisis dan menelaah pelanggaran kerja sama apa saja yang terjadi didalamya.

\section{HASIL DAN PEMBAHASAN}

Penelitian tentang pelanggaran prinsip kerja sama dalam percakapan yang disiarkan di televisi cukup meraik untuk dilakukan. Sebab biasanya dalam percakapan dengan orang penting pasti akan memperhatikan prinsip kerja sama dalam berbicara, namun apakah semua tuturan yang diucapkan selalu memperhatikan prinsip kerja sama atau malah masih ada yang melanggar, hal tersebut belum pernah penulis temukan di literatur sebelumnya, maka penulis dapat pastikan hasil penelitian akan dibahas adalah penelitian baru yang murni dilaukan oleh penulis. Dengan melakukan penelitian ini sedikit banyak akan menghasilkan kesimpulan tentang pelanggaran prinsip kerja sama dalam percakapan yang masih sering terjadi. mungkin sebelumnya ada literatur yang juga membahas tentang prinsip kerja sama, namun belum ada literatur yang membahas tentang pelanggaran prinsip kerja sama dalam percakapan antara Joko Widodo dan Najwa Shihab. Pelanggaran terhadap prinsip kerja sama sangat sering terjadi baik dalam percakapan sehari-hari atau nonformal maupun percakapan formal. Penelitian ini mengambil objek percakapan antara Najwa Shihab dan Joko Widodo dalam acara Mata Najwa di Metro TV. Topik yang dibahas pada saat itu ialah mengenai perjalanan dan perasaan Joko Widodo sebelum terpilih menjadi presiden hingga terpilih menjadi presiden. Penelitian ini hanya difokuskan pada percakapan antara Najwa Shihab dan Joko Widodo, meski dalam acara tersebut juga ada narasumber tambahan.
Hasil penelitian ini menyatakan bahwa terdapat pelanggaran prinsip kerja sama dalam percakapan yang melibatkan Najwa Shihab dan Joko Widodo. Bentuk-betuk pelanggaran tersebut dapat dilihat melalui empat maksim, yaitu maksim kualitas, maksim kuantitas, maksim relvansi, maksim cara.

\section{a. Pelanggaran Maksim Kuantitas}

Pelanggaran maksim kuantitas dalam acara Mata Najwa adalah pelanggaran yang paling banyak terjadi, namun penulis hanya melampirkan lima konteks percakapan saja yang termasuk melanggar maksim kuantitas. Berikut ini kutipan-kutipan percakapan anatara Najwa Shihab dan Joko Widodo yang melanggar maksim kuantitas.

Najwa: Karna yang nonton aja capek pak, yang ngelihat dan capeknya itu keknya bukan capek fisik tapi terkadang karna kalo yang saking cintanya nih mungkin ikutikutan marah. Yang pacaran ikut-ikutan putus. Saya dengar lo pak, ada yang putus karna beda-beda pilihan, jadi lelah secara emosional. Pak Jokowi jujur pak, emosi tenang?

Pak Jokowi: yaa jadi yang melelahkan itu memang kalo kita punya beban yang pertama, yang kedua kalo emosi kita teraduk-aduk. Itu saya gak pernah.

Konteks tuturan diatas terjadi ketika Najwa Shihab bertanya kepada pak Joko Widodo mengenai keadaan emosinya pasca kemenangan terpilih menjadi presiden. Dalam menjawab pertanyaan Najwa Shihab, terjadi pelanggaran maksim kuantitas yang dilakukan Joko Widodo. Pelanggaran maksim kuantitas terletak pada kalimat "yaa, jadi yang melelahkan itu memang kalo kita punya beban yang pertama, yang kedua kalo emosi kita teraduk-aduk. Itu saya ga pernah." Lawan tutur pada percakapan diatas melanggar maksim kuantitas, karena jawaban yang dituturkan lawan tutur terlalu bertele-tele dan tidak efisien. Seharusnya lawan tutur cukup menjawab pertanyaan sesuai yang dibutuhkan saja, misalnya emosi saya cukup tenang menanggapi persoalan tersebut. Sebab maksim kuantitas menuntut lawan tutur memberikan informasi 
sebagaimana yang diperlukan pertanyaan saja, tanpa melebih-lebihi informasi.

Najwa: tidak pernah bermimpi menjadi presiden?

Pak Jokowi: mimpi jadi wali kota juga tidak, mimpi jadi gubernur juga tidak, apalagi jadi presiden tidak pernah bermimpi.

Konteks tuturan diatas terjadi ketika Najwa Shihab bertanya kepada Joko Widodo mengenai apakah ia pernah bermimpi menjadi presiden, yang sebelumnya hanya seorang pengusaha meubel. Ketika Joko Widodo menjawab pertanyaan Najwa Shihab terjadi sebuah pelanggarang maksim kuantitas. Pelangagarang maksim kuantitas terletak pada kalimat "mimpi jadi wali kota juga tidak, mimpi jadi gubernur juga tidak, apalagi jadi presiden tidak pernah bermimpi." Lawan tutur pada percakapan diatas melanggar maksim kuantitas, karena jawaban yang dituturkan lawan tutur terlalu bertele-tele dan tidak efisien. Seharusnya lawan tutur cukup menjawab pertanyaan sesuai yang dibutuhkan saja, misalnya, saya dulu pernah bermimpi atau saya tidak pernah bermimpi sedikitpun. Sebab maksim kuantitas menuntut lawan tutur memberikan informasi sebagaimana yang diperlukan pertanyaan saja, tanpa melebihlebihi informasi.

\section{b. Pelanggaran Maksim Kualitaas}

Pelanggaran maksim kualitas dalam acara Mata Najwa juga beberapa kali terjadi, berikut ini kutipan-kutipan percakapan antara Najwa Shihab dan Joko Widodo yang melanggar maksim kualitas

Najwa: jadi panggung dadakan di pinggir jalan?

Pak Jokowi: mobil, biasanya mobil suruh naik diatas mobil itu disuruh ngomong.

Konteks tuturan diatas terjadi ketika Najwa Shihab menyatakan kepada Joko Widodo mengenai, panggung dadakan yang disediakan oleh masyarakat di pinggir jalan. Ketika Joko Widodo menjawab pertanyaan Najwa Shihab terjadi sebuah pelanggarang maksim kualitas. Pelangagarang maksim kuantitas terletak pada kalimat "mobil, biasanya mobil suruh naik diatas mobil itu disuruh ngomong". Lawan tutur pada percakapan diatas melanggar maksim kualitas, karena jawaban yang dituturkan lawan tutur terlalu tidak sejalan dengan pertanyaan. Seharusnya lawan tutur cukup menjawab pertanyaan sesuai yang dibutuhkan saja, misalnya, iya disediakan panggung dadakan di pinggir jalan. Sebab maksim kualitas menuntut seseorang sama sekali tidak diizinkan untuk berbicara tidak benar. Jika pertanyaan membutuhkan jawaban A, maka berilah jawaban A, tidak B ataupun C.

Najwa: ada juga yang lucu nih pak di foto di GBK, teman-teman kita akan tunjukkan foto ini, am foto ini... nah (menampilkan foto). Coba tolong dijelaskan pak, supaya ibu Iriana tidak berfikir macam-macam pak Jokowi. Itu siapa yang menjawi dagu?

Pak Jokowi: loh kalo seperti ini tidak sekali dua kali kok ratusan kali gitu loh dan dan istri saya tau karna selama kampanyekan ikut terus disamping saya di mobil, jadi di mobil yo diginikan (sambil memegang dagu).

Konteks tuturan diatas terjadi ketika Najwa Shihab menanyakan kepada Joko Widodo mengenai, seseorang yang menjawi dagunya. Ketika Joko Widodo menjawab pertanyaan Najwa Shihab terjadi sebuah pelanggarang maksim kualitas. Pelangagarang maksim kuantitas terletak pada kalimat "loh kalo seperti ini tidak sekali dua kali kok ratusan kali gitu loh dan dan istri saya tau karna selama kampanyekan ikut terus disamping saya di mobil, jadi di mobil yo diginikan (sambil memegang dagu)." Lawan tutur pada percakapan diatas melanggar maksim kualitas, karena jawaban yang dituturkan lawan tutur terlalu tidak sejalan dengan pertanyaan dan fakta dari jawaban yang diberikan juga tidak tentu kebenarannya mengenai istri Joko Widodo selalu ikut dengannya dan selalu duduk di mobil. Seharusnya lawan tutur cukup menjawab pertanyaan sesuai yang dibutuhkan saja, misalnya, ooh itu adalah rakyat kampung tamban. Sebab maksim kualitas menuntut seseorang sama sekali tidak diizinkan untuk berbicara tidak benar dan menuntut fakta dari ucapannya. Jika pertanyaan membutuhkan 
jawaban A, maka berilah jawaban A, tidak B atau yang lainnya.

Najwa: anda sudah diberi laporan berapa sisanya pak atau anda belum dapat laporan itu?

Pak Jokowi: $\mathrm{mm}$ beberapa hari ini saya tidak mengikuti karna beberapa hari pengeluaran yang paling banyak paling besar.

Konteks tuturan diatas terjadi ketika Najwa Shihab menanyakan kepada Joko Widodo mengenai, laporan sisa sumbangan kampaye. Ketika Joko Widodo menjawab pertanyaan Najwa Shihab terjadi sebuah pelanggarang maksim kualitas. Pelangagarang maksim kuantitas terletak pada kalimat "mm beberapa hari ini saya tidak mengikuti karna beberapa hari pengeluaran yang paling banyak paling besar". Lawan tutur pada percakapan diatas melanggar maksim kualitas, karena jawaban yang dituturkan lawan tutur tidak sejalan dengan pertanyaan dan fakta dari jawaban yang diberikan juga tidak tentu kebenarannya. Seharusnya lawan tutur cukup menjawab pertanyaan sesuai yang dibutuhkan saja, misalnya sisanya kira-kira 5000. Sebab maksim kualitas menuntut seseorang sama sekali tidak diizinkan untuk berbicara tidak benar dan menuntut fakta dari ucapannya. Jika pertanyaannya 'berapa' maka membutuhkan jawaban 'angka', maka berilah jawaban 'angka', tidak jawaban yang lain.

\section{c. Pelanggaran Maksim Relevansi}

Pelanggaran maksim relevansi dalam acara Mata Najwa juga beberapa kali terjadi, berikut ini kutipan-kutipan percakapan anatara Najwa Shihab dan Joko Widodo yang melanggar maksim relevansi.

Najwa: komplit, pesantren tak pernah sepi ya pak.

Pak Jokowi: kemudian di jawa Timur waktu lewat darat dari Malang kemudian kota Malang, kabupaten Malang dan menuju ke Blitar, kemudian menuju ke Tulung Agung, ke Trenggalek. Di Trenggalek diterima. sebelumnya di cegat di tengah jalan.
Konteks tuturan diatas terjadi ketika Najwa Shihab menyatakan kepada Joko Widodo mengenai, pesantren yang tidak pernah sepi. Ketika Joko Widodo menjawab pertanyaan Najwa Shihab terjadi sebuah pelanggarang maksim relevansi. Pelanggaran maksim relevansi terletak pada kalimat "kemudian di jawa Timur waktu lewat darat dari Malang kemudian kota Malang, kabupaten Malang dan menuju ke Blitar, kemudian menuju ke Tulung Agung, ke Trenggalek. Di trenggalek diterima. sebelumnya di cegat di tengah jalan." Lawan tutur pada percakapan diatas melanggar maksim relevansi, karena jawaban yang dituturkan lawan tuturtidak relevan dengan pernyataan sebelumnya. Seharusnya lawan tutur menjawab pernyataan tersebut harus sesuai/nyambung dengan topik yang sedang dibahas. misalnya, ya, masih komplit. Sebab maksim relevansi menuntut seseorang harus relevan, nyambung, dan sesui dengan topik pembahasan.

Najwa: adakah momen-momen yang

Pak Jokowi: tapi harus saya jelaskan pas ketemu ketemu masyarakat di daerah kemudian di pindok pesantren perlu saya jelaskan supaya isu itu tak berkembang kemana-mana tapi untuk dipikir saya gak mikir.

Konteks tuturan diatas terjadi ketika Najwa Shihab menanyakan kepada Joko Widodo mengenai, momen-momen. Ketika Joko Widodo menjawab pertanyaan Najwa Shihab terjadi sebuah pelanggarang maksim relevansi, karena pertanyaan yang dituturkan oleh Najwa Shihab belum selesai, namun Joko Widodo sudah menjawab pertanyaan tersebut dengan cepat. Sehingga hilangnya kesesuaian atau relevansi antara pertanyaan dengan jawaban. Sebab maksim relevansi menuntut seseorang harus relevan, nyambung, dan sesuai dengan topik pembahasan.

Najwa: masih banyak pertanyaan lagi.

Pak Jokowi: artinya kita kalo memang tidak ada beban yang amat sangat yang membebani kita ya menerima apupun ya enak-enak saja. Dan kalo kita terbebani oleh 
sesuatu e itu yang menjadikan sangat berat, ya kalo saya sih berjalannya seperti ini saja.

Konteks tuturan diatas terjadi ketika Najwa Shihab menyatakan kepada Joko Widodo mengenai, pertanyaan yang masih banyak. Tetapi Joko Widodo malah membicarakan hal lain sehingga terjadi sebuah pelanggarang maksim relevansi, karena pernyataan yang dituturkan oleh Najwa Shihab belum selesai, namun Joko Widodo sudah memulai tuturan yang lain. Sehingga hilangnya kesesuaian atau relevansi antaara pertanyaan dengan jawaban. Sebab maksim relevansi menuntut seseorang harus relevan, nyambung, dan sesui dengan topik pembahasan.

\section{d. Pelanggaran Maksim Cara}

Pelanggaran maksim cara dalam acara Mata Najwa juga beberapa kali terjadi, berikut ini kutipan-kutipan percakapan anatara Najwa Shihab dan Joko Widodo yang melanggar maksim cara.

Najwa: kemaren di Tugu Proklamasi anda mengatakan Prabowo dan hatta Rajasa adalah Patriot, adalah pejuang. Anda betulbetul memaknai kalimat itu pak?

Pak Jokowi: ya jadi, saya sampaikan bahwa dan saya suka meyakini bahwa beliau adalah bukan hanya patriot tapi juga negarawan.

Konteks tuturan diatas terjadi ketika Najwa Shihab menanyakan kepada Joko Widodo mengenai pernyataan Joko Widodo saat berada di Tugu Proklamasi. Ketika Joko Widodo menjawab pertanyaan Najwa Shihab terjadi sebuah pelanggarang maksim cara. Pelanggaran maksim cara terletak pada kalimat "ya jadi, saya sampaikan bahwa dan saya suka meyakini bahwa beliau adalah bukan hanya patriot tapi juga negarawan". Lawan tutur pada percakapan diatas melanggar maksim cara, karena jawaban yang dituturkan lawan tutur tidak memiliki kejelasan, sangat berbelit-belit, dan ambigu. Seharusnya lawan tutur cukup menjawab pertanyaan tersebut dengan kejelasan dan menghindari ketaksaan. Misalnya, ya, saya sangat memaknai kalimat yang saya ucapkan kemaren. Sebab maksim cara menuntut seseorang untuk menghindari ketaksaan, ketidakjelasan, berbeli-belit dan menganjurkan untuk bersikap teratur.

Najwa: marawis?

Pak Jokowi: saya ngantuk-ngantuk jadi semangat lagi, ya ya karna ini ada crek dug crek dugnya gitu masa disana ada crek dug crek dugnya saya ngantuk ngantuk kan gak mungkin.

Konteks tuturan diatas terjadi ketika Najwa Shihab menanyakan kepada Joko Widodo mengenai marawis. Ketika Joko Widodo menjawab pertanyaan Najwa Shihab terjadi sebuah pelanggarang maksim cara. Pelanggaran maksim cara terletak pada kalimat "saya ngantuk-ngantuk jadi semangat lagi, ya ya karna ini ada crek dug crek dugnya gitu masa disana ada crek dug crek dugnya saya ngantuk ngantuk kan gak mungkin". Lawan tutur pada percakapan diatas melanggar maksim cara, karena jawaban yang dituturkan lawan tutur tidak memiliki kejelasan, sangat berbelit-belit, dan ambigu. Seharusnya lawan tutur cukup menjawab pertanyaan tersebut dengan kejelasan dan menghindari ketaksaan. Misalnya, ya, bagi kita itu marawis, bukan malah menjawab dengan ketidakjelaan adanya bunyi crek dug crek. Sebab maksim cara menuntut seseorang untuk menghindari ketaksaan, ketidakjelasan, berbeli-belit dan menganjurkan untuk bersikap teratur.

Najwa: saya pikir sudah mulai menikmati, ga juga.

Pak Jokowi: kaget, kaget. Sering kaget dan dan ya bagaimana ya, ya memang adanya seperti itu.

Konteks tuturan diatas terjadi ketika Najwa Shihab menanyakan kepada Joko Widodo mengenai apakah Joko Widodo sudah menikmati tingkah masyarakat yang sering memegang dagu dan mencubitya. Ketika Joko Widodo menjawab pertanyaan Najwa Shihab terjadi sebuah pelanggarang maksim cara. Pelanggaran maksim cara terletak pada kalimat "kaget, kaget. Sering kaget dan ya bagaimana ya, memang adanya seperti itu". Lawan tutur pada percakapan diatas melanggar maksim cara, karena jawaban yang dituturkan lawan tutur tidak memiliki kejelasan, sangat berbelit- 
belit, dan ambigu. Seharusnya lawan tutur cukup menjawab pertanyaan tersebut dengan kejelasan dan menghindari ketaksaan. Misalnya, oo sama sekali tidak, bukan malah menjawab dengan ketidakjelasan kaget entah karena apa. Sebab maksim cara menuntut seseorang untuk menghindari ketaksaan, ketidakjelasan, berbeli-belit dan menganjurkan untuk bersikap teratur.

Najwa: anda mengecek, mengontrol pengelolaan dana itu?

Pak Jokowi: ya manajemen disana ada yang apa, ada bendaharanya, ada pembayarnya, ada kasirnya, dan juga ada auditernya, artinya setiap penggunaan itu beraudit.

Konteks tuturan diatas terjadi ketika Najwa Shihab menanyakan kepada Joko Widodo mengenai apakah Joko Widodomelakukan pengecekan dan melakukan konrol terhadap pengelolaan dana. Ketika Joko Widodo menjawab pertanyaan Najwa Shihab terjadi sebuah pelanggarang maksim cara. Pelanggaran maksim cara terletak pada kalimat "ya manajemen disana ada yang apa, ada bendaharanya, ada pembayarnya, ada kasirnya, dan juga ada auditernya, artinya setiap penggunaan itu beraudit.". Lawan tutur pada percakapan diatas melanggar maksim cara, karena jawaban yang dituturkan lawan tutur tidak memiliki kejelasan, sangat berbelit-belit, dan ambigu. Seharusnya lawan tutur cukup menjawab pertanyaan tersebut dengan kejelasan dan menghindari ketaksaan. Misalnya, ya saya mengontrolnya, bukan malah menjawab dengan memperkenalkan anggota manajemenya. Sebab maksim cara menuntut seseorang untuk menghindari ketaksaan, ketidakjelasan, berbeli-belit dan menganjurkan untuk bersikap teratur.

\section{KESIMPULAN}

Berdasarkan hasil penelitian tersebut, dapat ditarik kesimpulan bahwa terdapat pelanggaran prinsip kerja sama dalam percakapan antara Najwa Shihab dan Joko Widodo dalam acara Mata Najwa yang disiarkan di Metro TV, yang meliputi pelanggaran maksim kuantitas, pelanggaran maksim kualitas, pelanggaran maksim relevansi, dan pelanggaran maksim cara. Pelanggaran maksim kuantitas terdiri dari 12 tuturan, pelanggaran maksim kualitas terdiri dari 4 tuturan, pelanggaran maksim relevansi terdiri dari 3 tuturan, dan pelanggaran maksim cara terdiri dari 6 tuturan. Jadi, dalam percakapan anatar Najwa Shihab dan Joko Widodo terdapat pelanggaran prinsip kerja sama dalam bertutur sebanyak 25 tuturan. Pelanggaran prinsip kerja sama dalam acara Mata Najwa mengakibatkan komunikasi yang terjalin menjadi kurang efektif. Pelanggaran yang terjadi dalam acara Mata Najwa bisa saja disebabkan oleh faktor kepentingan, faktor tujuan, faktor permainan kata dan faktor situasi.

Berdasarkan pelanggaran yang terjadi dalam acara Mata Najwa, untuk dapat menghindari pelanggaran prinsip kerja sama dapat dilakukan dengan cara memperhatikan kosa kata tuturan, penggunaan bahasa yang digunakan harus lebih tertata, dan menjawab pertanyaan seperlunya saja dan jangan berbelitbelit agar komunikasi yang terjadi antara dua penutur tetap baik dan efisen serta mudah di pahami oleh pendengar.

\section{REFERENSI}

Achsani, F. (2019). Pematuhan Dan Pelanggaran Prinsip Kerja Sama Dalam Komunikasi Siswa-Siswi MAN 1 Surakarta. Tarling: Journal of Language Education, 2(2), 147-168. https://doi.org/10.24090/tarling.v2i2.292 1

Chaer, A. (2014). Linguistik Umum. In PT. Rineka Putra (p. 250). PT. Rineka Putra.

Fauziah, M. T., Emzir, E., \& Lustyantie, N. (2018). Pelanggaran Prinsip Kerja Sama dalam Tuturan Diskusi Kelas Bahasa Indonesia. JP-BSI (Jurnal Pendidikan Bahasa Dan Sastra Indonesia), 3(2), 5157. bsi.v3i2.722

Komalasari, F. M. P. K. dan K. (2019). Habituation to strengthen character of nationalism of students of the border 
region in the 21. Jurnal Pendidikan Karakter, 9(2), 216-230.

Mahsun. (2007). Metode Penelitian Bahasa. In Raja Grafindo Persada (p. 285). Raja Grafindo Persada.

Nuryani, dan D. A. K. P. (2013). Psikolinguistik. In Mahzab Ciputat (p. 180). Mahzab Ciputat.

Rahardi, Kunjana, Yuliana Setyaningsih, dan R. P. D. (2016). Pragmatik. In Erlangga (p. 206). Erlangga.

Samad, E. S. (2017). Prinsip Kerja Sama Dalam Dialog Antartokoh Pada Nonel "Rantau 1 Muara" Karya Ahmad Fuadi. Jurnal Bahasa Dan Sastra, 2(1), 8-16.

Setiawan, A., Basuki, R., \& Rahayu, N. (2017). Pelanggaran Prinsip Kerja Sama Percakapan Dalam Acara Mata Najwa Di Metro Tv. Jurnal KORPUS, 1(1), 1-9. https://doi.org/10.33369/jik.v1i1.3121

Sudaryanto. (1993). Metode dan Teknik Analisis Bahasa: Pengantar Penelitian Wahana Kebudayaan secara Linguistis. In Duta Wacana University Press (p. 390). Duta WacanaUniversity Press.

Surastina. (2011). Pengantar Semantik dan Pragmatik. In New Elmatera (p. 200). New Elmatera.

Yusri. (2016). Ilmu Pragmatik dalam Perspektif Kesopanan Berbahasa. In Deepublish (p. 258). Deepublish. 